\title{
PREFACE
}

This study proposes to show the unity, coherence, and continuity of the theme of slavery in Cuban narrative. Although there have been works published in and outside of Cuba pertaining to slavery, they are either limited to the early antislavery narrative or focus on one particular nineteenth- or twentieth-century author such as Cirilo Villaverde, Juan Francisco Manzano, Miguel Barnet, or Alejo Carpentier. There are other studies which treat the theme of blacks in Cuban, Caribbean, and Latin American literatures, but none has attempted to trace the theme of slavery from its inception to the contemporary period and understand it as a past and present literary concern.

From a broader perspective, this study strives to redefine the canon of Spanish American literature which has systematically relegated themes related to blacks to the margins of literary discourse. Leading scholars have successfully identified and classified important movements, trends, and authors and included them in the canon, but few have paid attention to slavery and blacks as a fundamental component of literature, history, and culture. For example, Villaverde's Cecilia Valdés, which I consider to be one of the most important, if not the most important, novel in nineteenth-century Spanish American literature, continues to receive little attention outside of Cuba. Cecilia Valdés should be read alongside José Mármol's Amalia and Jorge Isaacs's María, thus forming a nineteenth-century literary triangle between Cuba, Colombia, and Argentina and a trilogy of works whose titles contain the names of women.

Now that we are well into the postboom period or approaching the boundaries of a new Latin American discourse, other types of narratives and genres will gain the attention of readers. The novel of the boom period and the circumstances associated with its development fulfilled an important mission; that is, to bring Spanish America and its literature to the attention of the world, particularly the 
works of writers such as Gabriel García Márquez, Guillermo Cabrera Infante, Carlos Fuentes, Mario Vargas Llosa, and Julio Cortázar. As we enter a new period in Spanish American literature, we can look forward to exploring other writers and aspects of the literature which I believe are as important as those of the boom period. I am referring, for example, to feminist literature and the theme of blacks. From my perspective, Cecilia Valdés as well as Anselmo Suárez y Romero's Francisco, Alejo Carpentier's The Kingdom of This World, and Miguel Barnet's The Autobiography of a Runaway Slave, among others, and the themes they represent should be familiar to students of Spanish and Latin American literatures. Other works such as Lino Novás Calvo's El negrero and Manzano's Autobiografía are essential for the study of slavery but also for understanding the strategies of writing biography and autobiography, respectively. I hope this study will raise questions about canon and canon formation in general and blacks and slavery in particular and.inspire a fruitful dialogue among scholars regarding the value of the themes addressed in this book. Ultimately, I hope it will serve as an example for the study of slavery and blacks in nineteenth- and twentieth-century Spanish American literature.

This book could not have been written without the help and support of colleagues and friends. I owe special gratitude to Roberto González Echevarría and Antonio Benítez Rojo for their invaluable suggestions throughout the various stages of this manuscript. I have learned much from their ideas and suggestions. Their dedication, discipline, and work have provided me with a model I have attempted to follow. Many of their writings are reflected in mine.

I would also like to thank Sara Castro Klarén, Aníbal González, Bob Russell, Enrique Pupo Walker, Sylvia Molloy, Bob Márquez, and Randolph Pope, who have directly or indirectly supported this project. Their faith in my work gave me the energy and enthusiasm to overcome adverse circumstances and complete the manuscript. At Dartmouth, I was given invaluable assistance by the interlibrary loan officer, Patsy Carter, who helped to track down many obscure and difficult to obtain books. In addition, I received financial support in the form of a Dartmouth Junior Faculty Fellowship for the fall term of 1983 which allowed me to complete portions of the manuscript. I want to recognize Fred Berthold and Jim Tatum, members of the Committee Advisory to the President, for reading the manuscript and recognizing the value of its content. At Washington University in St. Louis, I would like to thank Randolph Pope, Horacio Xaubert, John Garganigo, Antonio Vera-León, Joseph Schraibman, 
and Nancy Schauum for taking me in as one of their own and creating a friendly and intellectual environment. I am also grateful to the graduate students in the Department of Romance Languages and Literatures for their valor in taking a seminar on Slavery in Cuban Narrative and allowing me a forum to express many of the ideas contained herein; they were patient but also challenging and asked many probing questions. I also owe much gratitude to my copy editor, Mary Hill, for her patience in reading the manuscript and her suggestions, and to Rae O'Connor for her help in preparing the index.

Finally, I would like to recognize members of my immediate family, Linda, Stephanie, and Gabriel, and my mother, Petra, for their sacrifice and support; above all, Linda for her trust and faith in me and her personal dedication in helping me complete the manuscript. I also owe special recognition to my close friends Peter and Nancy Beck for their unwavering support during difficult moments and for allowing me to use their home in Alburg Springs, along the shores of Lake Champlain, where I was able to edit portions of the manuscript.

W.L. 
THIS PAGE INTENTIONALLY LEFT BLANK 


\section{Literary Bondage}

Slavery in Cuban Narrative 
THIS PAGE INTENTIONALLY LEFT BLANK 